\title{
STEM Based Learning to Create Joyful Investigating Pumpkins for Mathematical Learning on Primary School
}

\author{
Ghenny Aosi \\ SDN 09 Manggis Ganting Kota Bukittinggi
}

\begin{abstract}
This study aimed to: (1) identify the validity and reliability of indicators of factors that This article was based on the results of classroom action research of STEM approach in investigating pumpkins at first grade of SDN 02 Aur Kuning Kota Bukittinggi. The students learn to know deeply about pumpkins that easily found in their sorrounding by investigating and combining science, mathematic, enggineering, drawing, and art in their learning process. The subject of this project was the first grader of 02 Aur Kuning elementary school students in Kota Bukittinggi. The methode used classroom action research methode in two cycles with two meeting per each cylce. Indikator of critical thinking that used in this study were basic operations of reasoning and metacognitive knowledge. The results of this research showed that by applying STEM approach in investigating pumpkin improved the learning outcome and students creative thinking in learning science and mathematic at elementary school in Bukittinggi.
\end{abstract}

Keywords: Joyful Learning, Investigating Pumpkins, STEM Based Learning

\section{@-}

\section{INTRODUCTION}

21 st century education requires teachers to always evolve to adapt to the progress of the times. The rapid advances in technology and information in this millennial era must be accompanied by an increase in teacher competence. The government has tried to improve the capacity of education improvement services in all sectors, one of which is to overhaul the Education Unit Level Curriculum into the 2013 Curriculum. Implementation of the 2013 Curriculum in Indonesia seeks to balance the progress of an increasingly rapid age. The application of an integrated integrative thematic approach mandated should be able to provide students with a comprehensive learning experience so that students have minimal competencies that can balance the cognitive development of their knowledge equipped with skilled skills to deal with the rapid development of science and technology.
One approach that is thought to be able to overcome the problems stated above is the approach of Science, Technology, Engineering, and Mathematics (STEM) in learning. The STEM approach is considered in accordance with the 2013 curriculum implementation pattern which has become a mandatory curriculum in schools since it was first launched in 2013. This is because the STEM approach combines multidisciplinary learning at one time and is in line with thematic approaches that become the soul of 2013 curriculum learning. STEM is an interdisciplinary learning approach which is a harmonious pair between problems that occur in the real world and problem-based learning. This approach is able to create a cohesive learning system and active learning because these four aspects are needed simultaneously to solve problems. The solution given shows that students are able to unite abstract concepts from each aspect [1].

In addition to improving students 'ability in solving problems, the STEM 
approach is considered capable of improving students' critical thinking skills because every aspect of STEM has special characteristics that distinguish between the four aspects. Each of the aspects helps students think critically to solve problems that are far more comprehensive if integrated. The four characteristics are based on the definitions described by Torlakson, namely: (1) science that represents knowledge of the laws and concepts that apply in nature; (2) technology is a skill used in managing society, organization, knowledge or designing and using an artificial device that can facilitate work; (3) engineering or engineering is the knowledge to operate or design a procedure to solve a problem; and (4) mathematics is the science that connects quantity, numbers and space which only requires logical arguments without or accompanied by empirical evidence. All of these aspects can make knowledge more meaningful if it is integrated in the learning process [2]; [3].

\section{LITERATURE REVIEW}

\section{STEM Approach}

In the current digital era, education certainly has also developed rapidly. One of them is STEM learning which began to boom in Indonesia around 2014, while in developed countries like America, Finland and Australia have known this learning since 2005. STEM which stands for (Science, Technology, Engineering and Mathematics) is an interdisciplinary learning approach that combines aspects of Science, Technology, Engineering and Mathematics [4]. Research conducted by the Hannover research institute (2011) shows that the main purpose of STEM Education is an effort to demonstrate holistic knowledge between STEM subjects [5]. Integration in the STEM learning system can be said to be successful if all aspects in STEM are found in each learning process for each subject.

The application of the STEM approach in learning is certainly integrated throughout the learning process. The four aspects of STEM take part in every implementation of the learning steps [6]. The steps of each implementation of these aspects are as follows; (1) Aspects of Science in the STEM approach defined by Hannover are the skills to use knowledge and scientific processes in understanding natural phenomena and manipulating these symptoms so that they can be implemented; (2) Technology Aspects are the skills of students in knowing how new technologies can be developed, skills in using technology and how technology can be used in facilitating human work; (3) Engineering aspects have five phases in the learning process; and (4) Aspects of Mathematics are skills used to analyze, reason, communicate ideas, solve problems and interpret solutions based on calculations and data mathematically.

\section{Joyful Learning}

Education is a future investment. Through education, students can develop all the potential that exists in themselves. Students can increase their knowledge of knowledge from those who do not know to know. Education strives to accommodate the potential of students and equip students to prepare life in the future. Education is closely related to the learning process or learning activities [7]; [5]. The existence of the teacher is an important component in the teaching and learning process. The teacher's job is to teach students.

In teaching students, teachers need to develop their competencies and techniques in teaching. Often teacher pay less attention to teaching techniques. The number of subjects that must be mastered by the teacher, making the teachers apply the lecture method from day to day so that students feel bored, bored, even lazy to follow the learning process [8][9]. This has an impact on the learning achievement of students. As a teacher, must be good at managing the class, packaging a learning to be interesting and fun for students.

Teachers can develop their professionalism in educating. Submission of learning with varied learning methods is one way to overcome students' boredom in learning[10]. 
This can be supported by the use of quality learning media. For example, the teacher can present learning material by utilizing existing technology. In addition, with a variety of creative and innovative learning methods, students are not saturated with material and are more developed[11]. Indeed, being a teacher should be up to date with the times. Being a teacher who has good technological abilities will help the student learning process[12]. With this atmosphere, it is expected to change the atmosphere of boredom in learning to be happy, more passionate, and motivated. Thus, student achievement has the potential to increase.

Interesting and fun learning is an alternative for teachers to improve their quality in educating students[13]; [14]. For this reason, the teacher must know the nature of learning and good learning. The success of the learning process is strongly influenced by the teacher's understanding of the nature. In addition to increasing the spirit of learning, interesting and fun learning also triggers a teacher to be more creative and innovative in creating learning that can attract students' attention in delivering the subject matter [15]; [16]. This is where the level of creativity and the skills of educating students will be seen, so that the teacher must be good at turning the brain. Hopefully, with the creation of interesting and enjoyable learning, meaningful learning will be achieved for students.

\section{RESEARCH METHODE}

This research was a classroom action research. According to classroom action research, the research problem that must be solved comes from the problem of the practice of classroom learning more professionally [17]; [18]. The procedure for carrying out this research follows the basic principles of general action research. As the subject in this study were the first grade students of SDN 02 Aur Kuning Mandiangin District Koto Selayan, Bukittinggi City. The number of class I students is 28 people. The number of male students is 8 people and the number of female students is 20 people. The consideration of the researchers taking the subject of the research is based on the observations of researchers on learning in class I that still use conventional methods. In addition SDN 02 Aur Kuning in Aur Birugo Tigo Baleh Subdistrict, Bukittinggi has students from various social backgrounds.

The research was conducted in the first semester of 2018/2019 school year. From the time of planning to writing the research report, it takes 2 months, from August to September 2018. The first cycle of the first meeting was held on Tuesday, August 14, 2018 starting at 08.30-10.40 WIB, the first cycle of the second meeting was held on Tuesday, August 212018 starting at 08.30-10.40 WIB. While the second cycle of the first meeting was held on Wednesday, August 222018 starting at 08.30$10.40 \mathrm{WIB}$ and the second cycle of the second meeting was held on Thursday, August 23, 2018 starting at $08.30-10.40$ WIB.

The research procedure carried out follows the classroom action research procedures, namely planning, implementing, observing, and reflecting. Before conducting research this activity began by determining the research schedule. Previously the researchers asked for approval from the Principal. After obtaining the time the research was carried out the next step was to study the 2013 curriculum. In the curriculum there were core competencies which were the general goals of learning that students had to achieve. Basic Competence is the translation of Core Competencies. The next activity is to make a lesson plan. In this lesson plan it is illustrated in detail what learning objectives will be achieved, activities undertaken in learning, both teacher activities and student activities and evaluation to determine the level of students' understanding of learning. In addition, researchers also make worksheet that will be given to students.

The implementation of this activity was carried out by researchers as practitioners and class I teachers as observers. Practitioners carry out classroom learning activities in the form of interaction activities between teachers and students, and students with students. Observation activities were carried out by peers as observers to observe the activities of 
students during the teaching and learning process, the students 'activities were recorded on observers' observation sheets. In the reflection activity, the researcher and teacher observe the observation sheets that have been carried out and discuss the strengths and weaknesses of the learning that has been done. If there are deficiencies, improvements are made to learning activities. The results of this joint reflection are used as an input to subsequent actions. In addition the results of reflection activities for each action are used to compile conclusions on the results of actions I and II. The indicator of the success of this study is shown by the following points, namely (1) there is an increase in learning outcomes, (2) there is an increase in teacher performance in the learning process by applying learning, (3) an increase in students' critical thinking skills. To process data on student learning outcomes will be used percentage techniques proposed by Syaiful (2006).

Table 1. Criteria for Completeness of Learning Outcomes

Criteria

Learning Outcome

\begin{tabular}{l|l} 
Very Good & $86-100$ \\
Good & $71-85$ \\
Fair & $56-70$ \\
Less & $<56$
\end{tabular}

\section{RESULT AND DISCUSSION}

\section{First cycle}

In the learning carried out for pumpkins investigation, the first cycle was carried out starting with explaining the benefits of food and drinks eaten for human life. The teacher begins learning by demonstrating various kinds of fruits and vegetables and conducting question and answer with students about the benefits of these fruits and vegetables for human life. Students are stimulated to mention the benefits of fruits and vegetables they eat everyday. Students are also asked to identify the vitamins and minerals contained in these foods. Students are divided into several groups and given student activity sheets which help students identify fruits and vegetables and their benefits.

Student activities in cycle I were still in the form of an explanation of fruits and students were asked to classify various kinds of fruits and vegetables, then asked to explain the reasons or basis for them to group the fruits and vegetables into the same group. Activity cycle I was carried out with a pattern of two meetings. At the second meeting, the teacher asks students to write down their experiences when they go to the market, buy the fruits and vegetables they have done with their parents. Students were also asked to calculate the amount of their shopping and given some fruit and vegetable prices, students were asked to explain what vegetables and fruits they would buy if they had a certain amount of money.

Students were asked to design, composition the fruits and vegetables they would eat every day for a week and present a list of their fruit choices in front of the class. Then students are asked to explain why they chose the fruits and vegetables. When teachers lure students with questions that require them to explore by relating their experiences to the lessons they get in school, students are also trained in their critical thinking skills. This is in line with Taylor's opinion that students must be stimulated with questions that link the schemata they have had before with the new knowledge they learn [19]; [20]. The results of the Cycle I study based on the improvement of student learning outcomes and the improvement of critical thinking skills observed by observers can be explained in the following table.

Table 2. Learning Outcomes and Students' Critical Thinking Ability Cycle I

\begin{tabular}{|c|c|c|}
\hline Cycle I & $\begin{array}{l}\text { Average } \\
\text { Learning } \\
\text { Outcomes }\end{array}$ & $\begin{array}{l}\text { Critical } \\
\text { Thinking } \\
\text { Ability }\end{array}$ \\
\hline Meeting 1 & 74 & $56 \%$ \\
\hline Meeting 2 & 77 & $68 \%$ \\
\hline Improvement & 3 & $12 \%$ \\
\hline
\end{tabular}


In general, class I students seemed happy in learning with the STEM approach. During this time, students are less stimulated by activities that involve multidisciplinary (science, mathematics, language, and engineering) in one lesson. When activities classify fruits and vegetables, students look enthusiastic and scramble to come forward to class to express their opinions. Classrooms that are usually quiet become crowded and noisy with students' voices. Even students who are usually quiet follow their hands up to the front of the class. Student activities during this cycle I take a lot of time when students work in groups. The teacher does provide more opportunities for students to discuss in their groups. This is in accordance with Daly's opinion which states that when students are fully involved with the task directed from the teacher, students will not realize that they are involved in interdisciplinary learning and they get two or three knowledge at a time [21]. Learning with the STEM approach is proven to improve students' critical thinking skills because they are able to criticize and be actively involved in learning. When viewed from the results of learning, the average student learning outcomes have indeed increased, but there are still subject matter that has not been achieved and there are still steps in the STEM approach that must be done by the teacher in accordance with planning, therefore learning continues to cycle II.

\section{Cycle II}

In the second cycle, activities continued with investigating pumpkinses. The teacher deliberately chooses pumpkinses for investigation because around the school environment, lots of pumpkins plants and students can easily take pumpkinses in their home yards. Some students carry young pumpkinses that are still green. The size of the pumpkinses brought by the students is also a large variety and a variety of conditions. Some are fresh and some are almost rotten. But the teacher makes the diversity of pumpkinses brought by students as an observation material for students to compare.
The activity begins with a general explanation of the steps the activities will be carried out by students in learning. Then the teacher divides students into groups. Each group consists of 5 to 6 people. Each group is given an activity sheet which must be completed with the pumpkinses they have brought. With the worksheet, students work in groups to investigate their pumpkinses. The following is a picture of activities carried out by students during activities.

The activity starts with determining the size of pumpkinses in large and small categories. Students choose one category and circle the categories according to their pumpkinses. Then then measure the length of the pumpkinses using a ruler and write them in centimeters $(\mathrm{cm})$. Then students were asked to weigh the weight of their pumpkinses and weigh the weight of their pumpkinses in groups. The results are written on the observation sheet that the teacher has shared. In this activity, the mathematical concepts highlighted in the activity. This is in accordance with Chiu's opinion that with STEM stating that the basis of STEM education involves the integration of these subjects by breaking the "silos" of disciplineindependent teaching that students often encounter throughout the day, and making connections to real-world contexts [22].

The next student activity is to describe the shape of their pumpkinses. In this activity the teacher expects students to be able to describe pumpkinses according to their actual pumpkinses. Pictures of pumpkinses made by students are colored and created creatively as possible so that they are similar to the pumpkinses they have. Students are seen trying to imitate their pumpkinses as closely as possible. When there is a "my pumpkins shape if split" column at the bottom right of the LKS, students split their pumpkinses and redraw their internal pumpkins shape and color the image. This activity is also carried out by students with enthusiasm. From the results of the observations and discussions of the teacher with the observer, students seemed to be trying hard so that the images they made were as 
close as possible to the original pumpkinses. Next the students' activities are to write down the uses of pumpkinses and write their pumpkins flavor. Students' answers are diverse, some make sweet, sour, bitter, bitter, salty, and others. Then students also write down the benefits of eating pumpkinses they know. The knowledge they learned about the benefits of pumpkinses in the first cycle. At the end, students were asked to write down their experiences with pumpkinses. It may be in the form of poetry, it can also be in the form of essays made by students in the column provided.

Based on student work sheets, it can be analyzed that students' ability to investigate pumpkinses has stimulated them to think critically and involve science, mathematics, and language lessons as well as learning. Students get not just one knowledge at a time, but can get a lot of knowledge. The ability of students in critical thinking increases according to the observations of teachers and observers. Student learning outcomes during learning also increase and the percentage of critical thinking skills in students increases. Student learning outcomes can be seen in the table below.

Table 3. Learning Outcomes and Cycle II Student Critical Thinking Ability

\begin{tabular}{lll}
\hline \multirow{2}{*}{ Cycle II } & $\begin{array}{l}\text { Average } \\
\text { Learning } \\
\text { Outcomes }\end{array}$ & $\begin{array}{l}\text { Critical } \\
\text { Thinking } \\
\text { Ability }\end{array}$ \\
\hline Meeting 1 & 78 & $71 \%$ \\
Meeting 2 & 82 & $78 \%$ \\
\hline Improvement & \multicolumn{1}{c}{4} & $8 \%$ \\
\hline
\end{tabular}

From Table 3 above it can be seen that there is an increase in student learning outcomes when compared to cycle I. Increased students' critical thinking skills also occur as much as $8 \%$. Learning with the STEM approach is proven to be able to trigger the achievement of several learning objectives in one learning time. This is in accordance with Mangunson's opinion which states that although school achievement is a cumulative process that combines mastery of academic and behavioral skills, most of the results of expert research on the application of the STEM approach show a view of the association between students' selfdevelopment capacity during learning and school outcomes [23]. Based on the results of the research it can be concluded that the STEM approach is proven to improve student learning outcomes while improving students' critical thinking skills in school. Knowledge gained by students at school can be applied in their environment and daily life.

\section{Conclussion}

Based on the results of the study and the discussion above, it can be concluded from this activity that the STEM approach is proven to improve student learning and critical thinking outcomes in class I SDN 02 Aur Kuning, Bukittinggi City. The STEM approach allows students to learn several subjects at a time of learning and gain diverse knowledge without students realizing that they are studying some of these subjects because there is no inter-level separation of lessons learned. For this study, it can be generally suggested to teachers that teachers should be able to use the STEM approach for subject matter that can be combined to be studied in one lesson time. Of course analysis of subject matter is needed before starting the lesson. The author warns that the author has not taken into account other processes in school that can increase or decrease the predictive power of the skills and behavioral actions that the author does. The model of educational achievement described in this paper is also based on the argumentation of the importance of interaction between individual skills and behavior and school support that students must obtain

\section{REFERENCES}

[1] D. F. Feldon, M. A. Maher, J. Roksa, and J. Peugh, "Cumulative Advantage in the Skill Development of STEM Graduate Students: A Mixed-Methods Study," Am. Educ. Res. J., vol. 53, no. 
1, pp. 132-161, 2016.

[2] STEM Task Force, "Innovate A blueprint for STEM in California public education," no. May, p. 7, 2014.

[3] S. Papadakis, M. Kalogiannakis, and N. Zaranis, "Improving Mathematics Teaching in Kindergarten with Realistic Mathematical Education," Early Child. Educ. J., vol. 45, no. 3, pp. 369-378, 2017.

[4] M. S. Corlu, R. M. Capraro Prof., and M. M. Capraro, "Introducing STEM education: Implications for educating our teachers for the age of innovation," Egit. ve Bilim, vol. 39, no. 171, pp. 7485, 2014.

[5] A. A. Barakabitze et al., "Transforming African Education Systems in Science, Technology , Engineering , and Mathematics ( STEM ) Using ICTs : Challenges and Opportunities," vol. 2019, 2019.

[6] J. M. Breiner, S. S. Harkness, C. C. Johnson, and C. M. Koehler, "What Is STEM? A Discussion About Conceptions of STEM in Education and Partnerships," Sch. Sci. Math., vol. 112, no. 1, pp. 3-11, 2012.

[7] S. Gehrke and A. Kezar, "The Roles of STEM Faculty Communities of Practice in Institutional and Departmental Reform in Higher Education," $\mathrm{Am}$. Educ. Res. J., vol. 54, no. 5, pp. 803833, 2017.

[8] M. Demir, H. Bacanli, S. Tarhan, and M. Ali Dombayci, "Quadruple thinking: Critical thinking," Procedia - Soc. Behav. Sci., vol. 12, pp. 545-551, 2011.

[9] N. M. Florea and E. Hurjui, "Critical Thinking in Elementary School Children," Procedia - Soc. Behav. Sci., vol. 180, no. November 2014, pp. 565572, 2015.

[10] E. Altintas and A. S. Ozdemir, "The Effect of Teaching with the Mathematics Activity Based on Purdue Model on Critical Thinking Skills and Mathematics Problem Solving Attitudes of Gifted and Non-Gifted Students," Procedia - Soc. Behav. Sci., vol. 46, pp.
853-857, 2012.

[11] S. A. Rodzalan and M. M. Saat, "The Perception of Critical Thinking and Problem Solving Skill among Malaysian Undergraduate Students," Procedia - Soc. Behav. Sci., vol. 172, no. 2012, pp. 725-732, 2015.

[12] S. Gregory, "Practice teaching: An inquiry into the experiences in developing an evaluation tool used in classroom observations," vol. 5, no. 1, pp. 63-74, 2016.

[13] T. Bergqvist and J. Lithner, "Mathematical reasoning in teachers' presentations," J. Math. Behav., vol. 31, no. 2, pp. 252-269, 2012.

[14] A. A. Genlott and Å. Grönlund, "Closing the gaps - Improving literacy and mathematics by ict-enhanced collaboration," Comput. Educ., vol. 99, pp. 68-80, 2016.

[15] M. H. Hopson, R. L. Simms, and G. A. Knezek, "Using a technology-enriched environment to improve higher-order thinking skills," J. Res. Technol. Educ., vol. 34, no. 2, pp. 109-119, 2001.

[16] I. Y. Malkova and P. V. Kiselyova, "Development of Personal Competences in Project-based Learning in the EFL Classroom," Procedia - Soc. Behav. Sci., vol. 154, no. October, pp. 254-258, 2014.

[17] N. Kunlasomboon, S. Wongwanich, and S. Suwanmonkha, "Research and Development of Classroom Action Research Process to Enhance School Learning," Procedia - Soc. Behav. Sci., vol. 171, pp. 1315-1324, 2015.

[18] C. Yigit and B. Bagceci, "Teachers' opinions regarding the usage of action research in professional development," J. Educ. Train. Stud., vol. 5, no. 2, p. 243, 2017.

[19] L. Taylor and D. F. Hochuli, "Defining greenspace: Multiple uses across multiple disciplines," Landsc. Urban Plan., vol. 158, pp. 25-38, 2017.

[20] L. D. English, "Stem: Challenges and Opportunities for Mathematics Education," pp. 4-18, 2015. 
[21] S. R. Daly, E. A. Mosyjowski, S. L. Oprea, A. Huang-Saad, and C. M. Seifert, "College students' views of creative process instruction across disciplines," Think. Ski. Creat., vol. 22, pp. 1-13, 2016.

[22] A. Chiu, C. A. Price, E. Ovrahim, and M. Ed, "Supporting elementary and middle school STEM education at the whole-school level: A review of the literature," Museum Sci. Ind. Chicago, pp. 1-21, 2015.

[23] K. Magnuson, G. J. Duncan, K. T. H. Lee, and M. W. Metzger, "Early School Adjustment and Educational Attainment," Am. Educ. Res. J., vol. 53, no. 4, pp. 1198-1228, 2016.

\section{Biodata Penulis}

Ghenny Aosi ${ }^{*}$, Ainil Nilam Suri ${ }^{2 *}$

I* SDN 09 Manggis Ganting Kota Bukittinggi; ghenny212@gmail.com

2* SDN 02 Aur Kuning, Kota Bukittinggi,

Indonesia: ainilnilam80@gmail.com 